\title{
MENERAPKAN TEKNIK PILAH - PILIH TUGAS \\ DALAM PJJ - IPA UNTUK MENINGKATKAN HASIL BELAJAR SISWA KELAS VIII A DI SMP N 1 POGALAN, TRENGGALEK \\ TAHUN PELAJARAN 2020/2021
}

\author{
SUSIANA \\ SMP Negeri 1 Pogalan, Trenggalek, Jawa Timur \\ e-mail: susianasusi805@gmail.com
}

\begin{abstract}
ABSTRAK
Penelitian ini bertujuan untuk meningkatkan hasil belajar siswa dengan menerapkan teknik pilah - pilih tugas yang tepat untuk diberikan ke siswa. Pengumpulan data dalam tulisan ini dilakukan dengan teknik tes dan análisis kajian pustaka serta pengalaman guru untuk menentukan apakah teknik pilah-pilih tugas yang diterapkan dalam pembelajaran dikatakan berhasil secara signifikan atau tidak berhasil. Berdasarkan hasil analisis data diketahui bahwa terjadi peningkatan hasil belajar siswa secara signifikan, dibuktikan terjadinya peningkatan persentase ketuntasan belajar IPA dari $56,67 \%$ menjadi $93,33 \%$.. Jumlah siswa yang mampu menyelesaikan tugasnya di akhir semester jika sebelum diterapkan teknik pilah - pilih tugas terdapat $66,67 \%$ orang siswa yang tidak dapat menyelesaikan tugas di akhir semester ternyata setelah diterapkan teknik pilah - pilih tugas meningkat menjadi 93,33\% yang berhasil menyelesaikan tugas. Hal tersebut juga didukung kesesuaian dengan kajian literatur sehingga dapat ditarik kesimpulan bahwa teknik pilah - pilih tugas dalam pembelajaran jarak jauh mata pelajaran IPA dapat meningkatkan hasil belajar siswa. Berdasarkan kesimpulan tersebut peneliti memberikan rekomendasi agar teknik pilah - pilih tugas dalam pembelajaran jarak jauh mata pelajaran IPA ini dapat dilanjutkan penerapannya.
\end{abstract}

Kata Kunci: Teknik Pilah - Pilih Tugas, Hasil Belajar

\section{PENDAHULUAN}

Sebagai salah satu dari sekian banyak dampak negatif pandemi Covid - 19, sistem pembelajaran jarak jauh (PJJ) merupakan langkah kebijakan yang diambil pemerintah untuk menyelamatkan dunia pendidikan di Indonesia. PJJ yang diterapkan sejak awal Maret 2020, dilaksanakan di bawah kepengawasan satuan tugas Covid - 19 dimana teknik daring dan luring secara insidental akan diberlakukan dengan melihat kondisi dan situasi penyebaran virus Covid - 19 di sekitar sekolah. Sudah tidak diragukan lagi bahwa pelibatan teknologi sangat berperan dalam pelayanan pendidikan saat PJJ. Pembelajaran IPA dalam praktik pembelajaran jarak jauh, guru memanfaatkan beberapa fitur google yang mendukung keterlaksanaanya. Rachmad Effendy (2021) mencantumkan dalam paparan materi GMT, bahwa diantara fitur - fitur google untuk menyelenggarakan pembelajaran jarak jauh tersebut antara lain: (1) whatsapp. Whatsapp digunakan guru untuk mengkondisikan siswa sebelum masuk ke kelas virtual. Melalui whatsapp, guru memberikan pengumuman awal tentang rencana kegiatan pembelajaran yang akan dilaksanakan. Guru juga mengingatkan melalui whatsapp tentang waktu pelaksanaan, materi pelajaran, bahan - bahan yang mungkin diperlukan, bahkan melalui whatsapp guru juga mengingatkan orang tua siswa untuk membangunkan putranya lebih pagi, sarapan dan lain lain. Yang jelas, whatsapp adalah sarana penghubung antara guru, siswa dan wali murid untuk berkoordinasi agar pembelajaran berlangsung dengan baik. (2) Google Meet atau Zoom meeting. Fitur ini digunakan untuk menyajikan pembelajaran tatap muka maya, dimana antara guru dan siswa dipertemukan secara "langsung" di kelas virtual. Ketika pembelajaran tatap muka maya berlangsung, guru dan siswa dapat berinteraksi layaknya pembelajaran di kelas yang sesungguhnya. Guru dapat menyampaikan materi pelajaran dengan audio visual dan siswa dapat mengajukan pertanyaan atau ide - idenya. Keadaan tersebut sangat mempengaruhi kondisi mental belajar siswa. Siswa yang sebelumnya belajar secara langsung tatap muka dengan guru di kelas, dimana siswa dapat berinteraksi langsung dengan gurunya, dengan teman 
- temannya, mereka dapat bertanya langsung saat menemui kesulitan, dapat melaksanakan kegiatan praktikum secara berkelompok dan sebagainya, (3) Google Calssroom. Fitur GC ini digunakan guru untuk membentuk dan mengelola kelas maya. Di dalam GC inilah guru akan mendelegasikan materi pelajaran dan tugas - tugas serta menerima hasil kerja siswa.

Moh. Suardi (2021:11) mengemukakan pendapatnya bahwa belajar merupakan perubahan diri seseorang yang dapat dinyatakan dengan adanya penguasaan pola sambutan baru, berupa pemahaman, keterampilan dan adaya perubahan sikap yang lebih baik.. Pembelajaran IPA dalam praktik pembelajaran jarak jauh, tetap harus dapat menumbuhkembangkan proses berpikir ilmiah (saintifik). Proses pembelajaran yang dilaksanakan guru harus memicu terjadinya berpikir ilmiah pada diri siswa. Terjadinya proses berpikir ilmiah pada diri siswa tersebut tidak terlepas dari bentuk - bentuk penugasan yang diberikan guru. Bukan berarti guru harus memberikan tugas yang gampang agar siswa mampu menyelesaikannya, tetapi lebih dari itu, kejelian guru dalam memilah dan memilih bentuk dan jenis tugas yang tepat akan mampu meningkatkan pemahaman siswa terhadap materi pelajaran yang akan berimbas pada peningkatan hasil belajarnya. Penugasan merupakan salah satu faktor utama pembelajaran dalam memperoleh masukan atau umpan balik pemahaman materi pelajaran baik bagi guru maupun bagi siswa. Bagi guru, tugas yang diberikan pada siswa digunakan untuk mengecek apakah setiap indikator materi sudah mampu dipahami oleh siswa atau belum. Selain itu guru juga memanfaatkannya sebagai refleksi terhadap pembelajaran yang sudah dilaksanakan maupun pembelajaran yang direncanakan selanjutnya. Sedangkan bagi siswa, tugas merupakan bentuk tanggung jawab yang diberikan guru yang harus diselesaikannya dimana nilai yang diperoleh merupakan cerminan hasil belajar yang sudah dilaksanakannya.

Dalam pembelajaran jarak jauh untuk mata pelajaran IPA, bentuk - bentuk penugasan yang dipilih guru sangat besar pengaruhnya terhadap hasil belajar siswa. Peneliti banyak menemukan siswa kesulitan menyelesaikan tugasnya sehingga di akhir semester bahkan ketika minggu - minggu terakhir mendekati penerimaan rapor, beberapa guru masih disibukkan menagih tugas siswa. Jumlah siswa di kelas VIII A tahun pelajaran 2020/2021 di SMP Negeri 1 Pogalan yang peneliti ajar berjumlah 30 siswa. Di akhir semester masih ada sekitar 10 siswa dari jumlah siswa satu kelas yang belum menyelesaikan tugasnya atau 66,67\% siswa yang lengkap mengumpulkan tugasnya untuk mata pelajaran IPA. Menurut pendapat peneliti, hal tersebut terjadi dikarenakan kurang tepatnya guru menentukan tugas yang diberikan ke siswa. Siswa menjadi merasa terlalu "berat" untuk menyelesaikan tugas sehingga di akhir semesterpun tugas mereka masih belum "kelar" semua. Sebagai akibat dari tugas yang belum tuntas dikerjakan, hasil belajar siswa banyak berada di bawah KKM mata pelajaran sebesar 70 . Pemberian tugas dengan menerapkan teknik pilah - pilih tugas dimana tugas yang diberikan ke siswa dipilih dan dipilah melalui beberapa pertimbangan diharapkan siswa menjadi lebih "ringan" untuk mampu menyelesaikan semua tugasnya. Hal tersebut pada akhirnya diharapkan pula akan meningkatkan hasil belajar siswa.

\section{METODE PENELITIAN}

Melaksanakan PTK merupakan kegiatan ilmiah yang dilakukan guru melalui proses berpikir sistematis dan empiris untuk memperbaiki kualitas pembelajarannya. Proses perbaikan yang dilakukan guru melalui PTK direncanakan secara matang, diamati kemudian dianalisis pengaruhnya, dicatat dan dipublikasikan. Menurut Cooper, (1990) dalam Wina Sanjaya, (2016) guru sebagai penentu pengambilan keputusan (decisión maker) memiliki tiga peran yaitu sebagai perencana pembelajaran, pelaksana pembelajaran (implementasi) dan sebagai penilai pembelajaran (evaluasi). Sebagaimana digambarkan oleh Cooper sebagai berikut: 


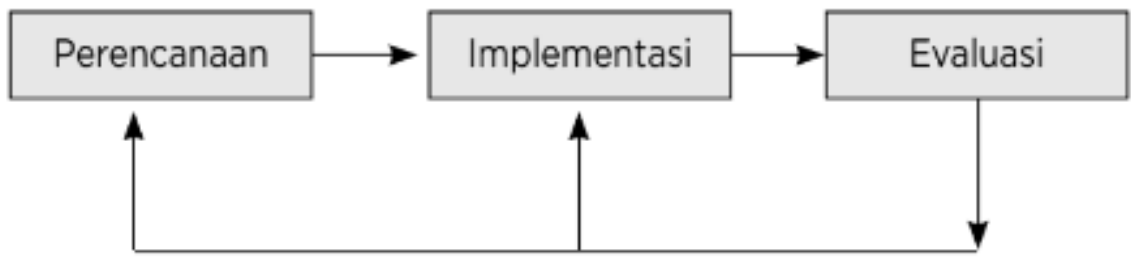

Gambar 1. Peran guru sebagai penentu keputusan

Dalam penelitian ini, tahap perencanaan yang dilakukan adalah merencanakan skenario yang akan dilaksanakan di kelas maya, seperti menyiapkan silabus dan RPP PJJ dan bahan mengajar serta instrumen penilaian. Materi IPA yang dipilih penelitian ini adalah materi di kelas VIII semester genap KD. 3.11 Getaran, Gelombang, Bunyi dalam Kehidupan Sehari-hari sedangkan sub materi pokok yang diambil adalah materi Getaran (Wahono dkk. (2017). Tahap selanjutnya yaitu pelaksanaan atau implementasi. Pada tahap kedua ini peneliti mengikuti rencana yang sudah disusun sesuai RPP PJJ. Pada tahap pelaksanaan ini peneliti menyajikan pembelajaran menggunakan kombinasi WA grup, google classroom dan google meeting, Pengamatan PJJ yang dimaksudkan adalah kelengkapan pengumpulan tugas siswa dan nilai hasil belajar siswa. ketika tindakan dilaksanakan di kelas maya, maka guna perbaikan diperlukan data-data hasil implementasi tindakan. Pada penelitian ini peneliti menggunakan instrumen berupa soal - soal tugas dan soal ulangan harian beserta kelengkapannya. Data - data yang dikumpulkan dalam penelitian ini berupa nilai hasil kerja tugas - tugas siswa dan nilai hasil belajar siswa yang dikirimkan online. Tahap selanjutnya adalah evaluasi. Pada tahap ini peneliti melakukan analisa data dilanjutkan membahas hasilnya. Dalam penelitian ini, pembelajaran jarak jauh IPA menerapkan teknik pilah - pilih tugas. Teknik pilah - pilih tugas yang dimaksud dalam penelitian ini adalah bahwa guru dalam memberikan tugas ke siswa harus melalui beberapa pertimbangan yaitu: (1) menentukan kompetensi dasar dan materi pokok, (2) menentukan indikator materi pokok yang esensial, (3) menentukan tujuan pembelajaran, (4) mengelompokkan tujuan pembelajaran menjadi dua bagian yaitu tujuan yang mengarah ke ranah koqnitif dan tujuan yang mengarah ke ranah aplikatif (psikomotor), (5) merancang tugas siswa baik untuk ranah kognitif maupun ranah psikomotor.

\section{HASIL DAN PEMBAHASAN}

Hasil

Berdasarkan data yang sudah diperoleh, selanjutnya data - data tersebut dianalisa. Analisa data yang berupa hasil kerja tugas - tugas siswa nilai dan direkap kelengkapan tugas tugas yang diserahkan. Sedangkan data yang berupa nilai hasil belajar siswa, dianalisa dengan cara dibandingkan dengan nilai kriteria ketuntasan minimal mata pelajaran IPA yang sudah ditetapkan yaitu sebesar 70. Jika siswa mendapatkan nilai hasil belajar sama dengan atau lebih dari 70 maka siswa tersebut termasuk dalam kriteria tuntas belajar.

Tabel 1. di bawah ini menunjukkan persentase siswa yang menyelesaikan tugas tugasnya antara sebelum dan sesudah diterapkannya teknik pilah pilih tugas dalam pembelajaran jarak jauh serta persentase ketuntasan belajar siswa pada pembelajaran jarak jauh IPA antara sebelum dengan sesudah menerapkan teknik pilah - pilih tugas. 
Vol. 1. No. 3 September 2021 e-ISSN : 2775-7188 | p-ISSN : 2775-717X

Tabel 1. Perbandingan data kelengkapan pengumpulan tugas siswa dan ketuntasan belajar siswa sebelum dan sesudah diterapkan teknik pilah - pilih tugas

Penerapan teknik pilah - pilih

No. Data tugas dalam proses

\begin{tabular}{clccc} 
& \multicolumn{2}{c}{} & \multicolumn{2}{c}{ pembelajaran } \\
\cline { 3 - 4 } & & Sebelum & Sesudah \\
\hline 1. & $\begin{array}{l}\text { Siswa yang lengkap } \\
\text { mengumpulkan tugas } \\
\text { Bendar }\end{array}$ & $66,67 \%$ & $93,33 \%$ \\
Ketuntasan & $\begin{array}{l}\text { Belajar } \\
\text { Siswa }\end{array}$ & $56,67 \%$ & $93,33 \%$ \\
\hline
\end{tabular}

Tabel 1. menunjukkan data siswa yang lengkap mengumpulkan tugas antara sebelum diterapkan teknik pilah - pilih tugas dengan sesudah diterapkan teknik pilah - pilih tugas dalam pembelajaran IPA terjadi peningkatan sebesar $26,66 \%$. Sedangkan ketuntasan belajar siswa juga mengalami peningkatan sebesar $36,66 \%$.

Jika data dalam tabel 1. di atas dinyatakan ke dalam bentuk diagram batang, maka diperoleh gambar sebagai berikut:

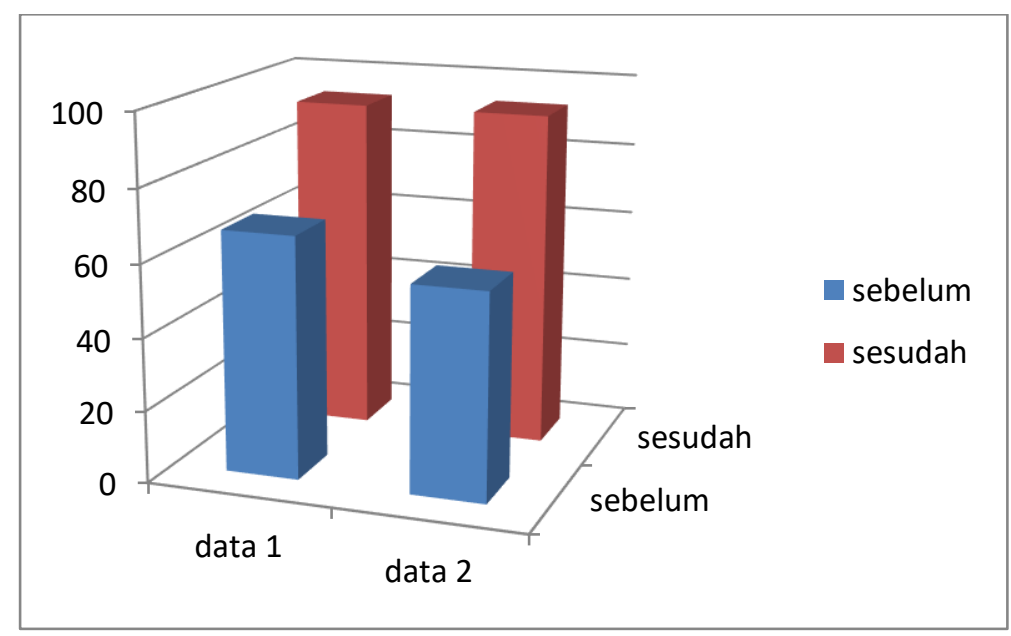

Gambar 2.

Diagram Perbandingan kelengkapan pengumpulan tugas siswa dan ketuntasan belajar siswa sebelum dan sesudah diterapkan teknik pilah - pilih tugas

Keterangan: data 1: data kelengkapan pengumpulan tugas siswa data 2: ketuntasan belajar siswa

Gambar 2. menunjukkan secara jelas perbandingan kelengkapan pengumpulan tugas siswa dan ketuntasan belajar siswa sebelum dan sesudah diterapkan teknik pilah - pilih tugas. Gambar 2. dapat diartikan bahwa penerapan teknik pilah - pilih tugas dalam pembelajaran IPA khususnya materi Getaran, Gelombang dan Bunyi dapat meningkatkan hasil belajar siswa.

\section{Pembahasan}

Tahap penugasan merupakan tahap latihan mengaplikasikan materi dalam siklus pembelajaran. Tahap penugasan ini memberi pengaruh terhadap $70 \%$ atau lebih terhadap pengalaman belajar secara keseluruhan. Pada tahap penugasan inilah pembelajaran siswa yang sebenarnya berlangsung (Moh. Suardi, (2021)). Dapat dikatakan berdasarkan pendapat Moh Suardi tersebut bahwa teknik pilah - pilih tugas merupakan faktor penting agar terjadi perubahan respons yang lebih baik pada diri siswa. Tahap penugasan mendorong siswa untuk membangun pemahamannya terhadap materi. Demikian pula pada saat ulangan harian, siswa 
dikondisikan untuk mampu memahami dan mengaplikasikan pengetahuannya untuk menyelesaikan soal - soal. Hasil analisa data menunjukkan bahwa terjadi peningkatan yang signifikan antara pengumpulan hasil tugas - tugas siswa dan ketuntasan hasil belajar siswa yang diketahui berdasarkan persentase yang diperoleh antara sebelum dan sesudah diterapkan teknik pilah - pilih tugas dalam pembelajaran jarak jauh mata pelajaran IPA untuk materi Getaran, Gelombang dan Bunyi.

Keputusan hasil analisa data tersebut relevan dengan pendapat Rita Khathir \& Taufiq A. Gani, (2021) yang mengemukakan bahwa keberhasilan belajar siswa selain harus ditinjau saat proses pembelajaran berlangsung dimana siswa mengerjakan tugas - tugas juga ditinjau dari kemampuan siswa dalam menyelesaikan soal ulangan harian di akhir pembelajaran. Sedangkan Sumiati \& Asra, (2012:200) juga menyatakan bahwa, keberhasilan proses bembelajaran dapat dilihat dari prestasi belajar yang dicapai siswa. Kegiatan evaluasi dalam penelitian ini berupa penugasan dan ulangan harian, akan memberikan informasi tingkat pencapaian belajar siswa baik dari aspek koqnitif maupun aspek psikomotor, dan jika dievaluasi secara lebih rinci akan diperoleh informasi tentang kesulitan belajar siswa yaitu tentang konsep - konsep yang belum dikuasai siswa. Informasi inilah yang nantinya akan menjadi umpan balik baik untuk guru dalam memperbaiki pembelajaran selanjutnya, juga berguna bagi siswa sebagai umpan balik untuk memperbaiki proses belajarnya.

Berdasarkan data yang diperoleh setelah dinyatakan dalam bentuk tabel dan dalam bentuk grafik, diperoleh hasil bahwa ketika guru mendelegasikan tugas - tugas ke siswa ternyata siswa yang sanggup menyelesaikan tugasnya terjadi peningkatan yang signifikan. Hal tersebut menunjukkan bahwa teknik pilah - pilih tugas yang dilakukan guru memberikan solusi bagi siswa dalam menyelesaikan tugas - tugasnya. Hal itu selaras dengan pendapat I Wayan Subagial \& I G. L. Wiratma, (2016) yang menyatakan bahwa penilaian hasil belajar siswa hendaknya mudah dirancang dan dilaksanaan serta tetap mengetengahkan prinsip-prinsip penilaian, seperti komprehensif, objektif, transparan, dan akuntabel. Penilaian yang dalam penelitian ini berupa penugasan dan ulangan harian juga digunakan untuk mengetahui kekuatan dan kelemahan proses pembelajaran, sehingga dapat dijadikan dasar pengambilan keputusan, misalnya apakah proses pembelajaran sudah baik dan dapat dilanjutkan atau perlu perbaikan dan penyempurnaan. Oleh sebab itu di samping kurikulum dan proses pembelajaran yang benar, juga perlu ada sistem penilaian yang baik dan terencana (Eny Winaryati, (2018)). Dapat diartikan bahwa pembelajaran jarak jauh IPA dengan menerapkan teknik pilah - pilih tugas merupakan langkah penilaian yang baik dan terencana. Terselesaikannya tugas - tugas siswa tersebut ternyata juga membawa dampak positip terhadap hasil belajar siswa terbukti data menunjukkan terjadinya peningkatan ketuntasan belajar siswa secara signifikan pada pembelajaran jarak jauh IPA khususnya pada materi Getaran, Gelombang dan Bunyi.

\section{KESIMPULAN}

Berdasarkan pembahasan dan kesesuaian literatur maka dalam penelitian ini dapat disimpulkan bahwa penerapan teknik pilah pilih tugas dalam pembelajaran jarak jauh mata pelajaran IPA benar benar dapat meningkatkan hasil belajar siswa. Teknik pilah - pilih tugas tersebut akan membantu siswa untuk meningkatkan pemahamannya terhadap materi pelajaran, dan juga mengkondisikan siswa untuk mampu menyelesaikan tugas - tugas yang merupakan kewajiban sebagai seorang siswa.

Guru sebagai penyelenggara pembelajaran di sekolah sebaiknya dalam memberikan tugas - tugas ke siswa melakukan teknik pilah - pilih tugas secara cermat dengan tujuan supaya pendelegasian tugas tidak sia - sia hanya karena siswa mengalami tanggungan yang berat sebagai akibat dari ketidakmampuannya menyelesaikan tugas - tugas sekolah. Melalui penerapan teknik pilah - pilih tugas dalam pembelajaran jarak jauh saat ini khususnya pada mata pelajaran IPA serta semua mata pelajaran pada umumnya diharapkan hasil belajar siswa terjadi peningkatan. 


\section{DAFTAR PUSTAKA}

Cahyani A, Listiana ID, Larasati S.Pd, (2020). Motivasi Belajar Siswa SMA pada Pembelajaran Daring di Masa Pandemi. Journal Pendidikan Islam, 3(1) : 123-140.

Eny Winaryati. (2018). Penilaian Kompetensi Siswa Abad 21. Semarang : Pendidikan Kimia, Fmipa Universitas Muhammadiyah Semarang (UNIMUS) ISBN: 978-602-5614-35-4,

I Wayan Subagia1 \& I G. L. Wiratma. (2016). Profil Penilaian Hasil Belajar Siswa Berdasarkan Kurikulum 2013. 5(1)

Moh. Suardi. (2018). Belajar \& Pembelajaran Ed. 1 Cet. 1, Deepublish. Yogyakarta: Author. Rachmad Effendy. (2021). Ppt. Materi Google Master Traineer. Jakarta : Kemendikbud.

Rita Khathir \& Taufiq A. Gani, (2021). Oase Pandemi Covid-19 Based On True Stories. Jilid 2. Aceh: Syiah Kuala University Press

Sarwa, S.S., M.M (2021). Pembelajaran Jarak Jauh : Konsep, Masalah dan Solusi, from https://www.google.com/search?tbm=bks\&q=pjj,

Sumiati \& Asra. (2012). Metode Pembelajaran. Bandung: CV Wacana Prima

Wahono dkk. (2017). Buku Guru IPA Kelas VII Kurikulum 2013. Jakarta : Kemdikbud

Wina Sanjaya. (2016). Penelitian Tindakan Kelas. 